\section{Organisation of Fire Research}

The Fire $\not$ esearch Organisation is a joint scheme in which gn industry and the Government are partners, sharing the cost equally. It will be responsible for the conduct of research on all aspects of the prevention and extinction of fires, on the safety of life in fires and the mitigation of damage, except that on the fire resistance of buildings the Organisation will collaborate with the building research organisation of the Department of Scientific and Industrial Research, where much research on this subject has already been done. A Fire Research Station will be jointly established. The capital cost is likely to be of the order of $£ 75,000-£ 100,000$, and the ultimate annual running cost up to $£ 50,000$, both shared equally between the Department and the Fire Offices' Committee. As part of its contribution to the capital cost, the latter will transfer its Fire Testing Station at Elstree to the Government. The following are the broad subjects on which research will clearly have to be undertaken, although it will be for the Fire Research Board to make a selection and allot priority of work: (1) methods of preventing the occurrence of fires; (2) methods of extinguishing fires and equipment ; (3) fire protection of buildings, that is, on the fire resistance of buildings, properties of building materials, and elements of structure, safety of life in fires, the prevention of the spread of fire within buildings and from building to building ; (4) other fire hazards, for example, ships, aircraft, special industrial hazards.

\section{Textile}

THE crucial importance of the relations between the textile industry and the textile machinery industry wagfentarisized in the report of the Working Party for $y$ cotton Industry, which recorded the broad apalossion that there is a clear need for more effprt $f$ Gpat Britain in regard to the perfection of the Lesign of the machinery and the development of new methods of processing. This report has now been followed by a broadsheet (No. 252), in which Political and Economic Planning sets forth the facts and findings of a preliminary survey of the textile industry. The War has given rise to a very large accumulated demand for textile machinery from all textile manufacturing countries, since they have been unable to obtain new machinery for six years. Normal obsolescence requirements have been accelerated by production at high pressure with a minimum of maintenance, and total demand for textile machinery is likely to remain at a high level for years. Moreover, Germany and Japan are for the moment almost completely out of the picture, and the United States, the only other country with a large potential capacity, is at present preoccupied with its domestic market and was never a large exporter of textile machinery. For the time being, the task of satisfying world demand will in the main fall upon the British industry; and in view of the need to encourage exports with favourable long-term prospects, P.E.P. suggests that textile machinery should be given a high priority, in respect both of the allocation of labour and raw materials and the proportion of output devoted to export.

The capacity of the industry must be increased well beyond its pre-war limits. In the spinning, weaving and finishing sections, this could be facilitated by making use of the engineering resources of other areas. In all sections of the industry shortage of labour is the limiting factor to increased capacity, and the productivity of the present labour force is low in comparison with other mechanical engineering industries. Among the most important measures of reorganisation and modernization recommended are mechanization of machine shops and foundries, which should increase productivity, and, by creating better conditions of work and pay, help to attract new recruits; an increase in the average size of producing unit, particularly at the foundry-level; and standardization of product. At present, too many different types of machinery are manufactured for work on identical fibres, with heavy demands on skilled labour and restricted possibilities of using automatic machine tools.

\section{Insect Control in Australia}

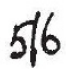

ThE use of D.DT as an agricultural insecticide has been jnvestignded by G. A. H. Helson and T. Greaves fJ. Gorin Sci. and Ind. Res., 18, No. 4, Canbare (Austratia, November 1945). They find thet it is. Affective against a variety of lepidopterous pests ofd also certain aphids, including Myzus persicce and I acrosiphum gei, which can act as vectors for virus diseases. D.D.T. was ineffective against the cabbage aphid Brevicoryne brassica, woolly aphis and red spider. On the debit side, bees were seriously affected by this insecticide when visiting the flowers of sprayed bean plants. The experiments were on varied scales, from laboratory tests to field trials, and several methods of application were used. D.D.T. dusts were also found by T. Greaves (ibid., 18, No. 2, May 1945) to provide the best control for a number of cabbage pests in north Queensland. Lead arsenate and calcium arsenate were also effective, but it would seem necessary to apply all three substances only to the early stages of growth of the crop, as they are toxic to man and higher animals. R. F. Powning (ibid., 18, No. 2, May 1945) has evolved a method for the analysis of D.D.T. and pyrethrins in kerosenebased sprays. The two insecticidal components are separated by passage through a column of alumina. D.D.T. passes through, and is then boiled with alcoholic caustic potash to liberate hydrochloric acid, which can be titrated with standard silver nitrate solution. Pyrethrins are liberated from the alumina and estimated by the usual methods. Wheat stored in bulk is sometimes attacked by Rhizopertha dominica and other insect pests. F. Wilson (ibid., 18, No. 2, May 1945) has shown that such outbreaks can be largely controlled by applying finely ground mag. nesite or dolomite to the surface of the mound. Smaller infestations can be dealt with by fumigation with carbon disulphide or ethylene dichloride.

\section{Indexing and Filing Unpublished Material H:}

THe report of the meeting on February 15, 1946, of the Association of Special Libraries and Information Burepheo discuss the "Indexing and Filing of Unpuplís Na Material" (see Nature, 157, 259; 1946) has foen published. It includes the papers by M.s. L. G. Thomerson on "Filing and Indexing sfstems of Patra", Mr. W. Ashworth on "Correspondence Filing Problems of the British Cast Iron Research Association", Mr. A. E. Dodd on "The Filing of Unpublished Material in the British Refractories Research Association", and by Miss D. Knight, "Unpublished Material in the Library of the National Institute for Research in Dairying", which have not already appeared in the Journal of Docu. 